Mahdi Majbouri*

\title{
Female Labor Force Participation in Iran: A Structural Analysis
}

\begin{abstract}
Low female labor force participation (FLFP) rate in Iran, at the time that women's education has been rising and their fertility rates have been falling, has remained a puzzle. By estimating elasticities of participation and hours with respect to wages (the extensive and intensive margins), this paper tries to shed some light on this puzzle. Using a structural estimation and controlling for selection, it depicts that the elasticity of women's participation in the labor force with respect to wages is quite large, especially for married women. Based on this, one may argue that women's participation is very sensitive to wages. But this is not consistent with the stylized facts about FLFP in Iran. The plausible implication of such elasticities, however, is that nonparticipating women have potential wages close to the wages of those who participate. Therefore, lower potential wages cannot be the factor that strongly dissuades women from participation. Instead, anticipated factors, such as labor market institutions and preferences, could be the underlying force hindering women from participation. The low FLFP rate can be explained better in light of these findings. The implications for policy and research are discussed.
\end{abstract}

Keywords: female labor force participation, structural estimation, Iran JEL Classification: J22, 053

\section{Introduction}

Women's education in Iran has consistently increased in the last decades. In 1980, for instance, an average Iranian woman aged 20 to 30 had 3.5 years of education, while her counterpart in 2010 obtained 10 years of education, a similar rise as the rest of Middle East and North Africa (MENA) region (data

*Corresponding author: Mahdi Majbouri, Babson College, 231 Forst St., Wellesley, Massachusetts 02457, USA, E-mail: mmajbouri@babson.edu 
source: Barro and Lee 2001). ${ }^{1}$ In almost the same period, between 1985 and 2005, fertility rate fell from about 6.5 to less than 2 children per woman; the fastest reduction in fertility in the world and larger than other countries in MENA (Salehi-Isfahani, Abbasi-Shavazi and Hosseini-Chavoshi 2010; Abbasi-Shavazi, McDonald and Hosseini-Chavoshi 2009; Majbouri 2015b). Although more education and lower fertility are associated with higher female labor force participation (FLFP), the FLFP rate remained low in the last three decades, at less than $30 \%$. This phenomenon, which is experienced across the MENA region, has yet remained a puzzle. ${ }^{2}$

Identifying the economics of labor force participation is one of the first steps in explaining the puzzle of FLFP in Iran. A review of the stylized facts about female labor in Iran reveals that rural women participate more than urban women in the labor market $(27.1 \%$ vs $15.6 \%)$. In rural areas, about $60 \%$ of female workers are unpaid family labor while in urban areas, about $60 \%$ are employees in public and private sectors (majority in public sector). More importantly, similar to the rest of the MENA region, but contrary to the rest of the world, married women, in both rural and urban areas, are significantly less likely to participate in the labor force than unmarried women. To understand the characteristics of female labor supply and its puzzle better, this paper estimates its elasticities with respect to wages. It demonstrates that FLFP in Iran, particularly for the urban and married women, has a very elastic supply.

Using recent datasets and a large sample size for urban and rural areas, this study provides a structural analysis of labor force participation of women in Iran. Correcting for selection, it estimates a structural model to calculate elasticity of participation with respect to wages (extensive margin) as well as elasticity of non-zero hours worked relative to wages (intensive margin). It finds that urban women have an upward sloping labor supply which is quite elastic with respect to wages (about 1.67). Urban married women have a large and statistically significant extensive margin (1.5), while never-married urban women have a small and insignificant one (0.62). The results for the intensive margin are also interesting as they are only statistically significant in urban areas, and are negative and relatively small ( -0.09 for all urban women, -0.07 for married urban women, and -0.27 for never-married ones). All of these results are robust to specification.

One interpretation of such high extensive margins is that women's participation is very sensitive to wages. But this interpretation does not match with the

1 For a discussion of women's education in Iran, please see Salehi-Isfahani (2005).

2 Please see Majbouri (2010) for a discussion of the puzzle and some of the characteristics of FLFP in Iran. 
puzzle of FLFP in Iran. If female labor supply is so sensitive to wages, rise in education, which leads to higher wages, should raise FLFP rates substantially. As we know, that did not happen. The other but more plausible interpretation is that we get such large elasticities because the non-participating woman at the margin has an imputed wage close to those of the participating ones. Based on these results, it can be argued that it is not the low potential wage that dissuades women from participation. Rather, there are other factors, such as the labor market institutions, particularly discrimination on the demand and supply sides, women's preferences, and lack of demand, that inhibit women from participation. This has important implication for policy makers as well as researchers, not only in Iran, but also in the MENA region, which shares the same FLFP characteristics and puzzle.

Most studies on FLFP in Iran offer qualitative analysis of the subject (see, for example, Alizadeh 2000; Karshenas 2001; Mehran 2003; Mehryar, Farjadi and Tabibian 2004; Moghadam 1995, 2000, 2011). The economics of FLFP in Iran has been quantitatively analyzed before, but not extensively. Esfahani and Bahramitash (2011) offer descriptive analysis of historical trends in FLFP in Iran. Salehi-Isfahani (2005) estimates a reduced form and finds expected correlations between household and individual characteristics with FLFP. Majbouri (2015a) employs a panel data and estimates the impact of an economic crisis on FLFP. Esfahani and Shajari (2012) use rural birth place as instrument for tertiary education and find that higher education increases FLFP. This study is the first that considers a structural model and estimates the elasticity of wages on female labor supply in Iran. The results contribute to our understanding of the FLFP puzzle in Iran and the MENA region.

The rest of the paper is organized as follows: In Section 2, I review the theory of LFP and discuss the estimation methods used to apply the theory to the data. Section 3 reviews the datasets used in this study in detail. Following that, in Section 4, I provide the empirical evidence for the model. In Section 5, I explain the implications of the results for policy and research.

\section{Labor Force Participation in Theory}

Economic theory has extensively modeled the factors affecting the decision to participate in the labor market (for a review of this literature see Killingsworth and Heckman 1986). A set of these models approaches the question as if there is a single lifetime period ("static" models). In these models, the individual has already been endowed with a set of characteristics and her decision to 
participate is usually affected by these predetermined characteristics and will not change. For example, her level of education and family background will not change. These models, which are usually applied to cross-sectional data are useful for understanding long-term decisions. Here, the canonical static model of labor force participation for a household is discussed.

Consider a household as a single entity that maximizes her utility function as follows:

$$
\begin{aligned}
& \max U_{i}\left(L_{i}^{f}, L_{i}^{m}, X_{i} ; E_{i}\right) \\
& \text { s.t. } p X_{i}+W_{i}^{f} L_{i}^{f}+W_{i}^{m} L_{i}^{m} \leq W_{i}^{f} T+W_{i}^{m} T+Y_{i} \\
& 0 \leq L_{i}^{f}, L_{i}^{m} \leq T
\end{aligned}
$$

in which $L_{i}^{f}$ and $L_{i}^{m}$ are the leisure time of the female and male members of household $i$, and $X_{i}$ is household $i$ 's consumption of a composite good. The exogenous elements of this model are $Y_{i}$, non-labor income, $p$, the price of the composite good, and $W_{i}^{f}$ and $W_{i}^{m}$, the hourly wage rates of female and male members, respectively. $E_{i}$ is a measure of all household characteristics that shape household $i$ 's utility function.

Solving for the optimal leisure time, one finds the structural model as follows:

$$
L_{i}^{j}=L_{i}\left(W_{i}^{f}, W_{i}^{m}, Y_{i}, p, E_{i}\right)
$$

in which $E_{i}$ contains household variables that shape the utility function especially with respect to labor force participation. It has an observed component $V_{i}$ as well as an unobserved part $e_{i}{ }^{3}$ If the utility function is quadratic, it can be shown that $L_{i}^{j}$ is a linear function and can be written as

$$
L_{i}^{j}=\rho+\varphi^{\prime} V_{i}+\varphi_{f}^{\prime} W_{i}^{f}+\varphi_{m}^{\prime} W_{i}^{m}+r^{\prime} Y_{i}+e_{i}+v_{i}^{j} \quad j=m, f
$$

Moreover, the normalized hourly wage rates (from now on, wages) are functions of predetermined (exogenous) characteristics such as schooling level and age. Wages can be specified as

$$
\begin{gathered}
W_{i}^{f}=W_{i}^{f}\left(Z_{i}^{f}, u_{i}^{f}\right) \\
W_{i}^{m}=W_{i}^{m}\left(Z_{i}^{m}, u_{i}^{m}\right)
\end{gathered}
$$

3 Note that, one can normalize wages by the price of the composite good, $p$, in the utility maximization problem and obtain $L_{i}^{j}$ which does not include $p$. 
in which $Z_{i}^{f}$ and $Z_{i}^{m}$ are the vector of observable characteristics of female and male members, such as schooling, respectively. $u_{i}^{f}$ and $u_{i}^{m}$ are mean zero constant variance disturbances of female and male members, respectively.

If the disturbances for wages and tastes in eqs [3], [4], and [5], i.e., $v_{i}^{j}$ and $u_{i}^{j}(j=f, m)$, are correlated, the Ordinary Least Squares (OLS) estimates of $\varphi_{f}^{\prime}$ and/or $\varphi_{m}^{\prime}$ are biased and inconsistent. To solve this problem, I instrument for wages and employ a "pseudo" two-stage least square (2SLS) approach. In the first stage, I estimate the wage equation using the instruments and then, with these estimates, predict wages for all individuals (not just those who worked). In the second stage, these predicted wages are used to estimate LFP equation (eq. [3]). This procedure, which is discussed in detail in Section 4.1, is similar but not identical to the 2SLS method. ${ }^{4}$

In this "pseudo" 2SLS, the instrument is individual education. The argument is that education only explains LFP through wages. In other words, we assume that education affects the decision to work only through wages. More education increases wages and increased wages in turn increase incentives to work. This is a common assumption for a static model in which education is an endowment earned in the past. Moreover, in the absence of experimental data, this assumption has been used in many studies to estimate labor supply elasticities (see Blau and Kahn 2007; Blundell and MaCurdy 1999). Blau and Kahn (2007) argue that using education as instrument for wages gives us a measure of elasticity with respect to permanent income (as opposed to intertemporal elasticities). In Section 4.1, I utilize this method to estimate a simpler form of eq. [3].

To obtain the reduced form equation, one can substitute normalized wage functions (eqs [4] and [5]) in eq. [2] and get

$$
L_{i}^{j}=L_{i}\left(V_{i}, Z_{i}^{f}, Z_{i}^{m}, Y_{i}, e_{i}, u_{i}^{f}, u_{i}^{m}\right) \quad j=f, m
$$

which can in turn be linearized into

$$
L_{i}^{j}=\alpha+\beta^{\prime} V_{i}^{j}+\gamma^{\prime} Z_{i}^{f}+\delta^{\prime} Z_{i}^{m}+r^{\prime} Y_{i}+e_{i}+\eta_{i}^{j} \quad j=m, f
$$

in which $\eta_{i}^{j}$ is a mean zero constant variance disturbance that includes $u_{i}^{f}$ and $u_{i}^{m}$. This reduced form shows us which household and individual characteristics are correlated with FLFP. Esfahani and Shajari (2012) have reported the results for this model in probit and IV probit format. The aim of this study is to estimate the structural model (eq. [3]) controlling for selection and endogeneity.

4 In 2SLS, we only predict wages for those observations used to estimate the first stage, i.e., those who had worked and reported wages. But, here, wages are also predicted for observations not used in the first stage, i.e., those who did not work or report wages. 


\section{Data}

Statistical Center of Iran (SCI) has been the main organization in charge of gathering micro datasets in the country in the past six decades. These relatively large datasets provide various statistics for policy makers. This study uses the Household Expenditure and Income Surveys (HEIS), a series of cross-sectional household surveys conducted annually since 1963 in rural areas and 1968 in urban areas. The surveys contain basic demographic information, ownership of assets, dis-aggregated expenditure, and income. Over the years, they have become richer as more questions were added. For instance, hours worked per day and days worked per week were asked since 2006.

Each year, new samples are drawn from the population. The samples are nationally representative and stratified at the urban and rural areas of each province. Sample selection follows a two-stage sampling method which has remained the same over the years. In the first stage, based on the most recent census, the total number of primary sampling units (PSUs) in each geographical block (rural or urban areas in each province) is determined, which is equal to the population in the block divided by five. ${ }^{5}$

In the second stage, a number of PSUs in each block are chosen to be surveyed. This number depends on the population and variance of some variables of interest, such as food expenditure, in that block. Hence, households have different probability of selection. For instance, more rural households have been selected. Probability of selection is known for each household and is taken into account whenever national average of a variable, like labor force participation, is estimated in this study.

Until 2005, the definition of employment in these surveys was limited to a person who works for at least two days during the week prior to the survey. Since the adoption of ILO standards in 2005, everyone who is working for at least one hour during the week prior to the interview is considered employed. Another issue with these surveys is that number of hours worked was not asked until 2005. Hence, it was not possible to calculate hourly wages, a major component of labor market analysis with these surveys. Surveys after 2005, however, collect hours worked as well as distribution of female and male wages.

The HEIS of 2006 through 2009 was used in this study. These years were selected because they were before the significant increase in international sanctions on Iranian economy, which radically changed the growth rate, imports and exports, government

5 Each PSU corresponds to a census track and consists of five households. Selected households are often neighbors living side-by-side. 
budget, and public expenditures. The economy was relatively stable during these years. ${ }^{6}$ The sample contains women aged between 25 and 65 . We divide the sample into urban and rural areas, or married and never-married and we use several individual and household-level characteristics in the analysis. The summary statistics of variables used are reported in Table 1 . Since the dependent variable (in the second stage as well as the selection model) is a dummy variable, some continuous variables such as education and age were transformed into categorical variables. Dummy

Table 1: Summary statistics.

\begin{tabular}{|c|c|c|c|c|}
\hline & Mean & Std. Dev. & Min & Max \\
\hline \multicolumn{5}{|l|}{ Rural sample } \\
\hline Illiterate & 0.49 & 0.5 & 0 & 1 \\
\hline Primary & 0.36 & 0.48 & 0 & 1 \\
\hline Middle school & 0.07 & 0.26 & 0 & 1 \\
\hline High school & 0.06 & 0.23 & 0 & 1 \\
\hline College and above & 0.02 & 0.15 & 0 & 1 \\
\hline Age & 40.9 & 11.48 & 25 & 65 \\
\hline No. of females b/w 15 and 18 & 0.28 & 0.54 & 0 & 4 \\
\hline No. of males b/w 15 and 18 & 0.31 & 0.56 & 0 & 5 \\
\hline No. of females above age 18 & 1.73 & 1.03 & 1 & 10 \\
\hline No. of males above age 18 & 1.55 & 0.98 & 0 & 8 \\
\hline Asset index & -0.89 & 2.06 & -5.44 & 6.38 \\
\hline In(owned home value) & 10.62 & 3.78 & 0 & 15.76 \\
\hline $\ln ($ wage $)$ & 9.52 & 0.91 & 6.26 & 12.93 \\
\hline LFP & 0.25 & 0.43 & 0 & 1 \\
\hline \multicolumn{5}{|l|}{ Urban sample } \\
\hline Illiterate & 0.24 & 0.43 & 0 & 1 \\
\hline Primary & 0.3 & 0.46 & 0 & 1 \\
\hline Middle school & 0.13 & 0.34 & 0 & 1 \\
\hline High school & 0.21 & 0.4 & 0 & 1 \\
\hline College $\&$ above & 0.13 & 0.33 & 0 & 1 \\
\hline Age & 40.15 & 10.89 & 25 & 65 \\
\hline No. of females b/w 15 and 18 & 0.22 & 0.48 & 0 & 6 \\
\hline No. of males b/w 15 and 18 & 0.24 & 0.49 & 0 & 4 \\
\hline No. of females above age 18 & 1.61 & 0.93 & 1 & 8 \\
\hline No. of males above age 18 & 1.48 & 0.91 & 0 & 9 \\
\hline Asset index & 1.21 & 2.16 & -5.44 & 7.5 \\
\hline In(owned home value) & 9.68 & 5.91 & 0 & 17.01 \\
\hline ln(wage) & 10.31 & 0.81 & 6.74 & 13.03 \\
\hline LFP & 0.15 & 0.36 & 0 & 1 \\
\hline
\end{tabular}

Note: Illiterate, Primary, Middle school, High school, and College and above are dummies equal to one if the individual's level of education is equal to those and zero otherwise. Asset index is computed following Sahn and Stifel (2000) using asset ownership dummies.

6 The result is robust to the choice of survey years. 
variables for each of these categories were defined and employed. For example, "Illiterate," "Primary," "Middle school," "High school," and "College and above" are dummies representing levels of education. Age was divided into ten-year categories ( 25 to 34, 35 to 44, etc.) and dummy variables were used for each. For instance, $I[24<$ Age $\leq 34]$ represents a dummy variable which is equal to one if age is between 25 and 34 and zero otherwise. Women aged 55 through 65 are the omitted group.

Numbers of teenage female and male members (between age 15 and 18) are included in the regression as these are children for whom many households, especially in urban areas, allocate considerable resources (to their education) so that they would have a higher chance of entering college. Numbers of adult female and male members (above age 18) are also included in this regression as a proxy for the household's available labor force that can be used to generate income.

In the data, assets are simply measured as the ownership of appliances (fridge, stove, TV, radio, cassette player, computer, etc.), transportation vehicles (car, motorcycle, and bike), and access to utilities (electricity, piped water, gas, telephone, and in recent years Internet). They are not reported in terms of their value but rather as dichotomous ownership dummies which are equal to one if the household owns the specific asset and zero otherwise. ${ }^{7}$ One way of measuring total asset ownership is to define a new variable that is the sum of these dummies. In this method, technically, there is no difference between owning a car and owning a radio as both increase the new defined variable by one unit.

Instead of giving the same weight to all assets, one can give different weights to various assets based on how much the ownership of an asset signals the wealth of the household. Sahn and Stifel (2000) use factor analysis to find weights for each type of asset. Their main argument is that weights should be determined by the data that are being used. In this method, assets owned by many households get small or negative weights. The fewer people owning an asset, the larger the weights will be, as it shows that the asset is more valuable. Following their method an asset index was constructed and used in this study. ${ }^{8}$

The summary statistics of variables used are reported separately for rural and urban areas in Table 1. Figure 1 depicts the distribution of female and male wages in these areas.

7 All these dummies measure assets at the household level. Female versus male ownership can have differential effects on female labor supply. Since ownership is defined for the household, it is not possible to test this differential impact and compare unitary and bargaining models.

8 The asset dummies used are owning a car, a motorcycle, radio, audio system, black and white and color TV, VCD or DVD player, computer, cell phone, refrigerator, freezer, stove, vacuum cleaner, washer, sewing machine, fan, all types of coolers, dishwasher, Internet, shower, kitchen, and central air conditioning system. 


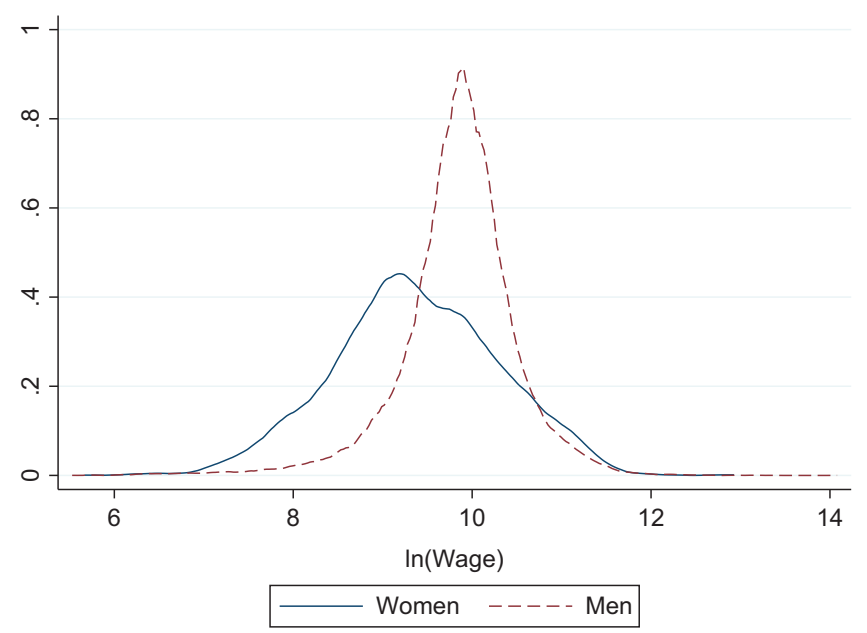

(a) Rural

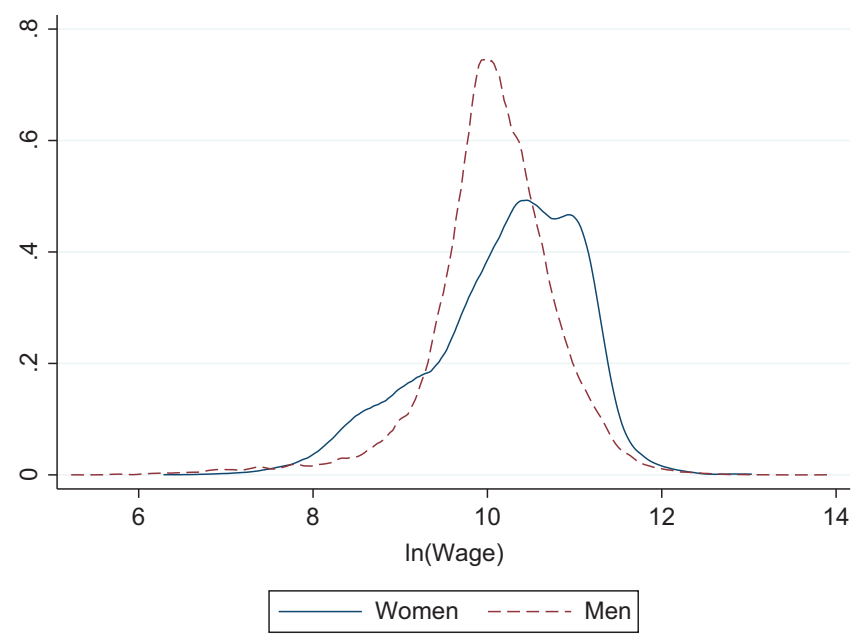

(b) Urban

Figure 1: Distribution of womens' and mens' wages in urban and rural areas.

\section{The Evidence}

\subsection{Estimating the Structural Model for LFP}

As discussed and shown in eqs [2] and [3], one of the main predictors of participation is wages. But, estimating the effect of wages on participation is 
difficult, as we do not observe wages for those who do not participate. Moreover, the error terms in eqs [3], [4], and [5], $v_{i}{ }^{j}$ and $u_{i}{ }^{j}(j=f, m)$, may be correlated with each other making OLS estimates biased.

To overcome these issues, as explained in Section 2, I employ education as an instrumental variable to predict wages for everyone (not just those who worked) and then, use those predicted wages instead of the actual wages to estimate eq. [3]. As discussed in Section 2, this is different from 2SLS. ${ }^{9}$

In order to implement this "pseudo" 2SLS method, we need to correct for selection on wage variable in the first stage, as wages are not observed for everyone. So, in the first stage, I estimate a two-step Heckman selection model of whether wages are observed for an individual. Estimating the structural model has the following steps:

1. In the first step of this Heckman selection model, inverse Mills ratios can be computed using a probit model in which household characteristics are the selection identifying variables.

2. In the second step, I estimate the log of hourly wages by employing education dummies as explanatory variables. Inverse Mills ratios, computed in the previous step, are included as regressors to correct for selection. This regression becomes like the first stage of a 2 SLS.

3. Using this regression, I then predict the log of wages for all women regardless of participation status, and substitute these predictions instead of wages in the second stage, i.e., eq. [3]. Education dummies are not included in this regression.

In order to satisfy the exclusion restriction in the second stage regression, we assume that education does not predict labor force participation directly, but only through wages. As explained in Section 2, this assumption is commonly used in the literature to estimate labor supply elasticities. ${ }^{10}$

Using predicted wages in the second stage gives us incorrect standard errors. Therefore, bootstrapping is used, for the whole procedure, to obtain correct standard errors in the second stage. First, a bootstrapped sample is

9 If it was a 2SLS method, wages would be predicted only for those observations used in the first stage, i.e., those who reported wages. In the second stage also, only those predictions would be used. In other words, we would have run the labor force participation regression only for those who worked. This is not possible, as the dependent variable in the second stage would be constant and equal to one.

10 For example, see Blau and Kahn (2007), and Blundell and MaCurdy (1999). As mentioned before, Blau and Kahn (2007) argue that using education as instruments for wages gives us a measure of elasticity with respect to permanent income (as opposed to intertemporal elasticities). 
drawn from the data. Then, the three steps, described above, were implemented on this sample. This procedure is repeated a thousand times, each time with a new bootstrapped sample. ${ }^{11}$ Re-sampling is implemented based on the cluster-year cells and standard errors are corrected for correlation in each cell. $^{12}$ The variables used are discussed in Section 3 and the summary statistics of them can be found in Table 1.

The first step regressions of Heckman selection model, for rural and urban areas, are reported in columns heading "Selection" in Table 2. These regressions

Table 2: Estimation of log of real wages for women aged 25 through 65 controlling for Heckman selection on wages, pooled data 2006-2009.

\begin{tabular}{|c|c|c|c|c|}
\hline & \multicolumn{2}{|r|}{ Rural } & \multicolumn{2}{|r|}{ Urban } \\
\hline & Selection & In(wage) & Selection & ln(wage) \\
\hline Primary & $\begin{array}{l}0.10^{\star \star} \\
(0.04)\end{array}$ & $\begin{array}{l}0.17^{\star \star \star} \\
(0.05)\end{array}$ & $\begin{array}{l}-0.07^{\star \star} \\
(0.03)\end{array}$ & $\begin{array}{l}0.23^{\star \star \star} \\
(0.06)\end{array}$ \\
\hline Middle school & $\begin{array}{l}0.17^{\star \star \star} \\
(0.06)\end{array}$ & $\begin{array}{l}0.71^{\star \star \star} \\
(0.09)\end{array}$ & $\begin{array}{l}0.15^{\star \star \star} \\
(0.04)\end{array}$ & $\begin{array}{l}0.58^{\star \star \star} \\
(0.07)\end{array}$ \\
\hline High school & $\begin{array}{l}0.63^{\star \star \star} \\
(0.06)\end{array}$ & $\begin{array}{l}1.12^{\star \star \star} \\
(0.11)\end{array}$ & $\begin{array}{l}0.71^{\star \star \star *} \\
(0.04)\end{array}$ & $\begin{array}{l}1.17^{\star \star \star} \\
(0.10)\end{array}$ \\
\hline College and above & $\begin{array}{l}1.60^{\star \star \star} \\
(0.06)\end{array}$ & $\begin{array}{l}1.82^{\star \star \star} \\
(0.24)\end{array}$ & $\begin{array}{l}1.98^{\star \star \star} \\
(0.04)\end{array}$ & $\begin{array}{l}1.88^{\star \star \star} \\
(0.23)\end{array}$ \\
\hline I[24<Age $\leq 34]$ & $\begin{array}{l}0.20^{\star \star \star} \\
(0.05)\end{array}$ & $\begin{array}{l}-0.39^{\star \star \star} \\
(0.10)\end{array}$ & $\begin{array}{l}0.16^{\star \star \star *} \\
(0.06)\end{array}$ & $\begin{array}{l}-0.57^{\star \star \star} \\
(0.07)\end{array}$ \\
\hline$I[34<$ Age $\leq 44]$ & $\begin{array}{l}0.39^{\star \star \star} \\
(0.05)\end{array}$ & $\begin{array}{r}0.04 \\
(0.10)\end{array}$ & $\begin{array}{l}0.64^{\star \star \star \star} \\
(0.05)\end{array}$ & $\begin{array}{l}-0.07 \\
(0.10)\end{array}$ \\
\hline I[44<Age $\leq 54]$ & $\begin{array}{l}0.28^{\star \star \star} \\
(0.04)\end{array}$ & $\begin{array}{r}0.00 \\
(0.09)\end{array}$ & $\begin{array}{l}0.55^{\star \star \star} \\
(0.05)\end{array}$ & $\begin{array}{r}0.05 \\
(0.09)\end{array}$ \\
\hline No. of females b/w 15 and 18 & $\begin{array}{r}0.02 \\
(0.02)\end{array}$ & & $\begin{array}{l}-0.07^{\star \star \star} \\
(0.02)\end{array}$ & \\
\hline No. of males b/w 15 and 18 & $\begin{array}{l}-0.03 \\
(0.03)\end{array}$ & & $\begin{array}{l}-0.04^{\star \star} \\
(0.02)\end{array}$ & \\
\hline No. of females above age 18 & $\begin{array}{l}0.05^{\star \star \star} \\
(0.01)\end{array}$ & & $\begin{array}{l}0.06^{\star \star \star} \\
(0.01)\end{array}$ & \\
\hline No. of males above age 18 & $\begin{array}{l}-0.12^{\star \star \star} \\
(0.02)\end{array}$ & & $\begin{array}{l}-0.15^{\star \star \star} \\
(0.01)\end{array}$ & \\
\hline
\end{tabular}

(continued)

11 Except for cases in which sample size was not large enough. In such cases, fewer iterations of bootstrapping were used. For instance, 200 and 500 iterations were used for the nevermarried women in rural and urban areas, respectively.

12 A cluster in a year forms a cluster-year cell. 
Table 2: (Continued)

\begin{tabular}{|c|c|c|c|c|}
\hline & \multicolumn{2}{|r|}{ Rural } & \multicolumn{2}{|r|}{ Urban } \\
\hline & Selection & In(wage) & Selection & In(wage) \\
\hline Asset index & $\begin{array}{l}-0.02^{\star \star} \\
(0.01)\end{array}$ & & $\begin{array}{l}-0.02^{\star \star \star} \\
(0.01)\end{array}$ & \\
\hline In(owned home value) & $\begin{array}{l}-0.01^{\star \star \star} \\
(0.00)\end{array}$ & & $\begin{array}{l}-0.00 \\
(0.00)\end{array}$ & \\
\hline 2007 & $\begin{array}{l}-0.03 \\
(0.09)\end{array}$ & $\begin{array}{l}-0.03 \\
(0.07)\end{array}$ & $\begin{array}{l}-0.02 \\
(0.04)\end{array}$ & $\begin{array}{l}-0.05 \\
(0.04)\end{array}$ \\
\hline 2008 & $\begin{array}{l}-0.07 \\
(0.08)\end{array}$ & $\begin{array}{l}-0.05 \\
(0.07)\end{array}$ & $\begin{array}{l}-0.06^{*} \\
(0.04)\end{array}$ & $\begin{array}{l}-0.15^{\star \star \star} \\
(0.03)\end{array}$ \\
\hline 2009 & $\begin{array}{l}-0.11 \\
(0.10)\end{array}$ & $\begin{array}{l}-0.08 \\
(0.08)\end{array}$ & $\begin{array}{l}-0.13^{\star \star \star *} \\
(0.04)\end{array}$ & $\begin{array}{l}-0.14^{\star \star *} \\
(0.04)\end{array}$ \\
\hline Constant & $\begin{array}{l}-2.05^{\star \star \star} \\
(0.07)\end{array}$ & $\begin{array}{l}8.57^{\star \star \star} \\
(0.51)\end{array}$ & $\begin{array}{l}-2.23^{\star \star \star} \\
(0.07)\end{array}$ & $\begin{array}{l}9.01^{\text {***}} \\
(0.40)\end{array}$ \\
\hline$[0.5 \mathrm{em}] \lambda$ & & $\begin{array}{r}0.27 \\
(0.20)\end{array}$ & & $\begin{array}{r}0.15 \\
(0.15)\end{array}$ \\
\hline F-stat - selection vars ${ }^{\dagger}$ & $158.01^{\star \star \star}$ & & $129.13^{\star \star \star}$ & \\
\hline F-stat - instruments $\ddagger$ & & $241.48^{\star \star \star}$ & & $51.83^{\star * *}$ \\
\hline Observations & 69,155 & 69,155 & 64,658 & 64,658 \\
\hline
\end{tabular}

Note: This table depicts wage regressions corrected for Heckman selection mode. The dependent variable in column heading "Selection" is whether wage is observed or not and in column heading "In(wage)" is log of real wages. For summary statistics of variables and their description, see Table 1 and Section 3. I $[X<$ Age $\leq Y]$ is a dummy equal to one if Age is larger than $X$ but smaller or equal to $Y . /[55<$ Age $\leq 65]$ is the omitted group. Selection identifying variables are No. of female and male teenage and adult members, asset index, and log of owned home value. Education dummies in column heading "In(wage)" are instruments for log of real wages in the second stage regressions reported in Table 3. Bootstrapped standard errors, resampled at cluster level and computed using 1000 replications, are in parentheses. Cluster random effects were employed.

${ }^{\star} p<0.10,{ }^{* \star} p<0.05,{ }^{\star * *} p<0.01$.

$\dagger$ This $\mathrm{F}$ statistic tests whether the selection identifying variables are jointly significant.

$\ddagger$ This $\mathrm{F}$ statistic tests whether the education dummies which are the instruments for log of wage in the regression in Table 3 are jointly significant.

are basically similar to the reduced forms in eq. [7], estimated using probit with the dependent variable representing whether wage was reported in the data or not. The selection identifying variables are the household characteristics: Number of females and males between age 15 and 18 (teenagers), number of females and males above age 18 (adults), asset index, and log of owned home value. Almost all selection identifying variables have statistically significant coefficients, especially in urban areas. The F-test shows that these coefficients 
are also jointly significant. The second step, which is the first stage of a "pseudo 2SLS" is reported in column heading "ln(Wage)." The dependent variable is the log of real wages and the regressors are education, age, and year dummies, as well as the inverse Mills ratio to correct for selection. ${ }^{13}$ In these regressions, education coefficients are increasing as the level of education increases. This is not surprising but it is interesting to see it in Iran as well. The F-statistics for testing the joint significance of instruments are significant and large (241.48 for rural areas and 251.83 for urban ones). The statistics are significantly larger than 10, the threshold below which instruments are generally considered weak.

Coefficients of age dummies show that age profile is concave. Wages are the lowest for the young ( 25 to 34 ) but they do not change much after one passes the age of 35. The year dummies show that women's wages did not change in rural areas between 2006 and 2009 but they continuously fell after 2007 in urban areas. Even though the inverse Mills ratios are insignificant, it does not mean that they should not be included in the first stage. Their exclusion can change the magnitude and significance of other coefficients in the first and second stages.

Using these estimates, one can predict wages for all individuals in the sample, whether they worked or not. These imputed wages are used in the structural model, i.e., eq. [3], instead of log of wages. Other covariates are variables used in the selection model regressions (columns heading "Selection" in Table 2) except education dummies. ${ }^{14}$ The second stage is a linear probability model with cluster random effect to control for correlation inside clusters. Table 3 depicts these regressions for urban and rural areas.

The main coefficient of interest, coefficient of predicted log of real wages, $\ln$ ( wage), is strongly significant in both urban and rural areas but is larger in the urban areas. For every $1 \%$ rise in wages, the likelihood to participate in rural and urban areas increases by 0.11 and 0.26 percentage points, respectively. Average LFP rate as well as elasticities computed at those averages are reported at the bottom of the table. ${ }^{15}$ These elasticities are particularly large for urban women as $1 \%$ increase in wages increases their LFP by $1.67 \%$. For rural women, $1 \%$ increase in wages increases their participation by only $0.41 \%$.

13 This regression is estimated jointly with the probit regression using Stata Heckman command to get correct standard errors.

14 Education dummies are instruments for wages and hence excluded from the second stage, i.e., LFP regression in Table 3.

15 Elasticities (or extensive margins) are equal to $\frac{\varphi_{f}^{\prime}}{l f p} \times 100$, in which $\varphi_{f}^{\prime}$ is the coefficient of wage in the structural model. 
Table 3: Linear probability model of labor force participation on predicted log of real wages from regression in Table 2 for women aged 25 through 65, pooled data 2006-2009.

\begin{tabular}{|c|c|c|}
\hline & Rural & Urban \\
\hline \multirow[t]{2}{*}{$\ln (\widehat{\text { wage }})$} & $0.11^{\star \star \star}$ & $0.26^{\star \star \star}$ \\
\hline & $(0.01)$ & $(0.03)$ \\
\hline \multirow[t]{2}{*}{$I[24<$ Age $\leq 34]$} & 0.02 & $0.14^{\star \star \star}$ \\
\hline & $(0.01)$ & $(0.03)$ \\
\hline \multirow[t]{2}{*}{ I[34<Age $\leq 44]$} & $0.03^{\star \star}$ & $0.05^{\star *}$ \\
\hline & $(0.01)$ & $(0.02)$ \\
\hline \multirow[t]{2}{*}{ I[44<Age $\leq 54]$} & $0.04^{\star \star \star}$ & -0.00 \\
\hline & $(0.01)$ & $(0.02)$ \\
\hline \multirow[t]{2}{*}{ No. of females b/w 15 and 18} & $0.03^{\star \star \star}$ & $0.01^{\star \star}$ \\
\hline & $(0.00)$ & $(0.00)$ \\
\hline \multirow[t]{2}{*}{ No. of males b/w 15 and 18} & $0.02^{\star \star \star}$ & $0.01^{\star \star}$ \\
\hline & $(0.00)$ & $(0.00)$ \\
\hline \multirow[t]{2}{*}{ No. of females above age 18} & $0.03^{\star \star \star}$ & $0.04^{\star \star \star}$ \\
\hline & $(0.00)$ & $(0.00)$ \\
\hline \multirow[t]{2}{*}{ No. of males above age 18} & $-0.01^{\star \star \star}$ & $-0.01^{\star \star \star}$ \\
\hline & $(0.00)$ & $(0.00)$ \\
\hline \multirow[t]{2}{*}{ Asset index } & $-0.01^{\star \star \star}$ & $-0.01^{\star \star \star}$ \\
\hline & $(0.00)$ & $(0.00)$ \\
\hline \multirow[t]{2}{*}{ In(owned home value) } & 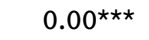 & $0.00^{\star \star \star}$ \\
\hline & $(0.00)$ & $(0.00)$ \\
\hline \multirow[t]{2}{*}{2007} & -0.00 & 0.01 \\
\hline & $(0.03)$ & $(0.01)$ \\
\hline \multirow[t]{2}{*}{2008} & -0.03 & $0.02^{\star \star}$ \\
\hline & $(0.03)$ & $(0.01)$ \\
\hline \multirow[t]{2}{*}{2009} & $-0.05^{\star}$ & $0.02^{\star}$ \\
\hline & $(0.03)$ & $(0.01)$ \\
\hline \multirow[t]{2}{*}{ Constant } & $-0.79 * \star \star$ & $-2.41^{\star \star \star}$ \\
\hline & $(0.14)$ & $(0.37)$ \\
\hline Observations & 69,155 & 64,658 \\
\hline Average LFP rate (in \%) & 27.1 & 15.6 \\
\hline Elasticities & 0.41 & 1.67 \\
\hline
\end{tabular}

Note: Dependent variable is a dummy equal to one if the individual is participating in the labor force and zero otherwise.

For a description and summary statistics of other covariates, please see Tables 1 and 2 . $\ln$ ( $\widehat{\text { wage }}$ ) is the predicted log of real wages from the first stage regression reported in Table 2. Education dummies are the instruments for log of real wage in the second stage in Table 3. Bootstrapped standard errors, resampled at cluster level and computed using 1000 replications, are in parentheses. Cluster random effects were employed.

${ }^{\star} p<0.10,{ }^{\star \star} p<0.05,{ }^{\star \star \star} p<0.01$. 
The question is why these elasticities, especially in urban areas, are large. One implication of the result is that a small change in wages increases female participation significantly. But this is not plausible as it does not fit the FLFP puzzle in Iran. If a small increase in wage raises FLFP, the rise in women's education, in the last two decades, should increase their participation substantially - since more education raises wages. As we know from the FLFP puzzle, this has not happened.

The other explanation is that we get such high elasticities, because the potential wages imputed for non-participating women on the margin of participation are very close to wages of women who participate. Therefore, the reason that they do not participate in the labor force cannot be wages, rather other factors, such as supply and demand side discriminatory institutions, lack of demand for female labor, and women's preferences. This argument is consistent with the female labor market in Iran. For example, the fact that the rural elasticity is smaller can be similarly attributed to the differences between the urban and rural areas in discriminatory institutions and demand for female labor.

In rural areas, there is less potential discrimination on both supply and demand sides. On the supply side, men, who are, by law, in charge of their wives' and daughters' decision to work, are more likely to let their wives or daughters work, since the majority of rural women work as unpaid family labor for their husbands, fathers, or "male guardians" and these men have close to full supervision on them. For example, they can make sure that little contact would be made with other men on the job. In addition, there is less information asymmetries $^{16}$ for the employers as they know women in the village very well. This reduces discrimination on the demand side of the market and increases demand for female labor. The types of jobs available in the urban areas do not offer the same conditions as in rural areas and hence one expects more men limit labor force participation of women on both the supply and demand sides.

In addition to less potential discrimination, there is more demand for female labor in rural areas. The availability of farms and family businesses in rural areas ensures that ample work is available for women as unpaid family labor. In urban areas, however, the opportunities for unpaid family labor is not available and hence, one observes more barriers to women's participation there. ${ }^{17}$ Another

16 such as adverse selection and moral hazard.

17 The fact that more women can work in rural areas because there is more unpaid family labor available may not be necessarily beneficial for women. One may argue that work becomes empowering when it is for wage and creates income for the individual. On the contrary, it can be also argued that although unpaid family labor does not provide income for women, it can increase their bargaining power in the household, as their labor creates economic value. 
reason for lower demand for female labor in the urban areas could be that employers (mistakenly) perceive men to be more productive than women in urban jobs. FLFP rate which is about twice as large as that of rural areas ( $27.1 \%$ vs $15.6 \%)$ is consistent with all these arguments about more discrimination, or lack of demand in urban areas.

The other reason that can explain high elasticities is women's preferences. As mentioned, high elasticities show that non-participating women on the margin have similar imputed wages as the participating ones. Nevertheless, they do not participate. If a large number of women see work as a burden added to their other obligations, housework and child care, or simply prefer the housework to market work, they do not enter the labor force despite the fact that their wages are similar to those who participate.

There are four age groups in the sample: 25 to 34, 35 to 44, 45 to 54, and 55 to 65 (the omitted group). As the coefficients show, in rural areas, the older one gets, the more she participates, while in urban areas it is the opposite. Rural women aged 45 to 54 participate more than other age groups followed by women aged 35 to 44. This is because women at these age groups are likely to have passed their fertile period and do not have to take care of small children any more. This frees up their time to participate in the labor markets. But in urban areas, the younger one is, the more she participates. This could be because of two factors: marriage and/or a generational difference. Some studies argue that women leave the labor market after marriage, and hence, younger women who are less likely to be married participate the most. This has been challenged by Salehi-Isfahani and Egel (2010). Using the youth school to work transition survey, they show that young women (aged 18 to 28) continue to work even after they get married. They are, however, silent on the older women's work transition after marriage, as the data only survey the youth. It could still be the case that the older women tended to leave the market after marriage. This brings us to another argument that explains the pattern in age coefficients in urban areas: the generational difference. Young women's attitudes toward marriage, gender equality, and work are different from the older generations in many respects (Kurzman 2008; Keddie 2006; Hooglund 2011). For instance, using various surveys collected between 2000 and 2003, Kurzman (2008) shows that educated young women, who are growing in numbers, have significantly more feminist attitudes of various sorts than other Iranians. He finds that educated young women are significantly more likely to work outside home, marry later, give birth later, have fewer children, and have more egalitarian marriages than other Iranian women.

More teenage females and males increase participation in both areas. In Iran, households, especially in urban areas, invest considerable resources on the 
education of their teenage children, particularly in this age group, and prepare them for the national college entrance examination. This exam is critical in shaping the future of the child. Therefore, we expect that the households try to acquire more resources, both money and time, for this investment. On the one hand, households need more income to be able to pay for the tuition of quality high school education as well as future college tuition, but, on the other hand, they may like to spend more time with their kids improving the quality of their education through home schooling. The former will entice mothers to participate in the labor force while the latter persuades them to stay at home. But there are two reasons that explain why women prefer to work more when they have more teenage daughters than sons: first, households are saving more for their daughters' future dowry when they are at this age, and second, teenage females in the household may contribute to home production and make more free time available for their mothers.

Presence of one more adult female in the household increases the likelihood of women working by about 0.03 percentage points in both urban and rural areas. This is not large or surprising, as more adult females in the household would increase the number of people who can potentially contribute to home production, and hence, provides more free time to more female members to contribute to the labor market. In addition, since these adult females are at the age of marriage, saving for their dowries is a strong motivation for all members of the household to work. Interestingly, more adult male members have negative correlation with FLFP. The coefficient is smaller than the coefficient for adult females but in the opposite direction. Adult males in the household usually contribute to household income by working in the labor market. Since households with more adult males may have more sources of income, they are less in need of income brought by adult females, and hence, fewer women would work in such households.

Assets are negatively correlated with urban women's participation but positively correlated with men's. Home value has a small but positive correlation with participation. As the price of a home increases by $10 \%$, women's participation increases by about 0.02 percentage points. The sign of the coefficient is surprising but it is too small and potentially captures unobserved characteristics. These results, for the most part, are consistent with the expectations.

In both urban and rural areas of Iran, there is a significant difference between the married and unmarried women's participation rates. This difference may be the result of discriminatory and/or non-discriminatory factors, such as women's preferences. Whatever caused it, one can divide the sample into two groups: currently married and never-married people, and re-estimate the three steps, 
Table 4: Linear probability model of labor force participation on predicted log of real wages for married and never-married women aged 25 through 65, pooled data 2006-2009.

\begin{tabular}{lcrrrr}
\hline & & Rural & & Urban \\
\cline { 2 - 3 } & Married & Never-married & & Married & Never-married \\
\hline In $(\widehat{\text { wage }})$ & $0.05^{\star \star \star}$ & 0.38 & & $0.18^{\star \star \star}$ & 0.28 \\
& $(0.01)$ & $(0.37)$ & & $(0.02)$ & $(0.30)$ \\
Observations & 55,525 & 8,002 & 53,026 & 6,414 \\
Average LFP rate (in \%) & 26.2 & 35.7 & 12.0 & 45.0 \\
Elasticities & 0.19 & 1.06 & & 1.50 & 0.62 \\
\hline
\end{tabular}

Note: Dependent variable is a dummy equal to one if the individual is participating in the labor force and zero otherwise. $\ln$ ( wage) is the predicted log of real wages from the first stage regression in which education dummies are the instruments for log of real wage here. For a summary statistics and description of other covariates, please see Tables 1 and 2 . Bootstrapped standard errors, resampled at cluster level and computed using 1000 replications, are in parentheses. Cluster random effects were employed.

${ }^{\star} p<0.10,{ }^{\star \star} p<0.05,{ }^{\star \star *} p<0.01$.

i.e., the Heckman selection, first stage, and second stage, for each sub-group. The results are reported in Table 4. The coefficient of log of wages in the second stage regressions is only significant for married women (both in urban and rural areas). ${ }^{18}$ This is very interesting as it is consistent with the explanations discussed above that the more discrimination there is, the larger elasticity we estimate. The large estimated elasticity is because the predicted wages for married women who do not participate are close to wages of participating married women. Therefore, the difference in wages should not be a key predictor of participation, rather it should be because of other factors such as discrimination on the supply or demand side. We find a large (significant) elasticity for married women because, first, their husbands should sanction their decision to work, and hence, they face more discrimination than never-married ones on the supply side. Moreover, on the demand side, the employers may prefer not to hire married women, because of various costs such as maternity leave, which can be argued as a form of discrimination. Note that estimated elasticities for never-married women are too noisy and statistically insignificant in both urban and rural areas.

18 Other coefficients in this regression as well as the Heckman selection model and the first stage regressions are available upon request. 


\subsection{Estimating the Structural Model for Hours}

After estimating the elasticity of LFP with respect to wages, or the extensive margin, the natural next step is to estimate the elasticity of hours worked with respect to wages, or the intensive margin. The econometric framework is similar to what was done in Section 4.1. Here, log of hours worked (instead of LFP) is regressed on predicted log of wages. Predicted log of wages is obtained from the same regressions explained in Section 4.1 and depicted in Table 2. Since log of non-zero hours worked is used as the dependent variable in the second stage, a two-step Heckman selection model should be used to correct for selection. The procedure is exactly the same as that discussed for LFP, above.

Table 5 reports this structural model across urban and rural areas as well as marital status. The coefficient of log of wage represents the elasticity since the dependent variable is in terms of $\log$ as well. As shown, this elasticity is insignificant for all rural women, including married and never-married ones. But, we get statistically significant and negative elasticities for urban women. The intensive margin for all urban women is -0.09 , meaning a $1 \%$ increase in wages decreases hours worked for urban women by about $0.09 \%$. The elasticity is larger (in absolute value) for never-married women than married ones $(-0.27$ vs -0.07$)$. This could essentially be because $65 \%$ of married employed women

Table 5: Linear estimation of log of hours worked on predicted log of real wages for women aged 25 through 65, pooled data 2006-2009.

\begin{tabular}{|c|c|c|c|c|c|c|}
\hline & \multicolumn{3}{|r|}{ Rural } & \multicolumn{3}{|r|}{ Urban } \\
\hline & All & Married & Never-married & All & Married & Never-married \\
\hline \multirow[t]{2}{*}{$\ln (\widehat{\text { wage }})$} & -0.03 & -0.05 & -0.02 & $-0.09 \star \star \star$ & $-0.07^{\star \star \star}$ & $-0.27^{\star \star \star}$ \\
\hline & $(0.05)$ & $(0.04)$ & $(0.07)$ & $(0.02)$ & $(0.02)$ & $(0.04)$ \\
\hline Observations & 2,415 & 1,594 & 575 & 5,517 & 3,878 & 1,222 \\
\hline Average hours & 36.8 & 35.2 & 39.0 & 36.9 & 34.7 & 41.4 \\
\hline
\end{tabular}

Note: Dependent variable is the positive (non-zero) hours worked by an individual in the week preceding the survey. Similar to Tables 2 and 3, a 2SLS procedure with a Heckman selection model was used to estimate elasticity of hours worked with respect to log of hours (intensive margin). The first stage of the 2SLS as well as the first step of Heckman selection model are available upon request. In(wage) is the predicted log of real wages from the first stage of a 2SLS in which education dummies are the instruments. For the summary statistics and description of other covariates, please see Tables 1 and 2. Bootstrapped standard errors, resampled at cluster level and computed using 1000 replications, are in parentheses. Cluster random effects were employed.

${ }^{\star} p<0.10,{ }^{\star \star} p<0.05,{ }^{\star \star \star} p<0.01$. 
work in public sector compared to $40 \%$ of never-married ones. Public sector has more fixed-hour schedules and changing hours worked is not easily possible. ${ }^{19}$

\section{Conclusion}

This paper studied LFP for Iranian women by applying a canonical static model to the data. The structural estimation showed that urban women have an upward-sloping supply curve, with a large elasticity (1.67). Dividing the sample into married and never-married women, we saw that the elasticity is only pronounced for married women, in both urban and rural areas.

The most plausible implication of such large elasticities is that the nonparticipating woman, at the margin, has a potential wage very close to the wages of the participating women. Therefore, these lower potential wages are not what dissuade women from participation. There should be other factors on the demand and/or supply side of the labor market that strongly hinder women from participation.

On the demand side, low demand for female labor, because of statistical and preferential discrimination, or because of (assumed) productivity differences, could be a culprit. The fact that educated women in Iran are more likely to be employers or self-employed than educated men (as shown by Esfahani and Shajari 2012) could be evidence of this low demand for female labor. Another piece of evidence is the high unemployment rate for women (more than 30\%). Many studies on countries in MENA confirm that the discriminatory institutions on the demand side of the labor market hinder female participation (see, for example, Ilkkaracan 2012; Sayre and Hendy forthcoming; Hakimian 2007; Assaad and El-Hamidi 2009). More research is necessary to understand the characteristics of demand for female labor and find potentials for policy interventions. There are, however, several policies that can be considered: one is to create incentives, such as tax breaks, for employers. Although it could be effective, this policy may not be optimal as it creates externalities and deadweight loss. Another option is to provide economic incentives, such as subsidized loans, for female self-employment and entrepreneurship. Depending on the incentive, this policy may be costly and not quite effective (as entrepreneurship depends on many personal and environmental factors and economic incentives may have a small impact on them).

19 The standard deviation of hours worked for urban women in the public sector is 12.8 hours while in the private sector it is 17.7 hours. 
On the supply side, two factors might be impeding women's participation: One is patriarchy and the other is women's own preferences. Several studies have discussed the role of supply factors in low FLFP rates in the MENA region (see, for example, Hayo and Caris 2013; Witte 2011). Preferences of male guardians of women (husbands, fathers, etc.) strongly shape women's participation in the market. By law, women need to acquire permission from their male guardians. Changing the laws and preferences is not easy and may even take generations. But, the process of globalization would speed up this process. Another issue is women's own preferences: some also argue that a share of women do not want to participate in the labor force even if there was no patriarchal discrimination. For example, Hayo and Caris (2013) show that women with strong traditional identities have a five percentage point lower chance of entering the labor market. Another reason could be that women prefer taking care of children instead or that they want to have flexible working hours. One policy to affect such preferences is to provide tax relief on income of mothers whose children need childcare, or tax subsidies for companies that offer flexible working hours or the possibility of working at home.

But, one solution with almost no dead-weight loss, for both the demand and supply factors, is to speed up the process of economic development. As the economy becomes more service-oriented and industries such as finance, insurance, higher education, and health care flourish, demand for high skilled workers increases. As a result, highly educated women, whose numbers are growing rapidly in Iran, ${ }^{20}$ would find more positions and higher wages available for them, which, in turn, increases FLFP rate substantially. In addition, economic development integrates the economy more in the globalized world. Potrafke and Ursprung (2012) showed that economic and social globalization have positive impacts on social institutions and improve gender equality. Producing and consuming globalized products as well as improved modes of communication gradually shape people's preferences away from traditional and non-egalitarian ones. For instance, Witte (2011) shows that an additional one dollar per person spent on American books in a Gulf Cooperation Council country raises the female share of total labor by $1.5 \%$.

Considering these, the potentials for future research on the demand and supply of female labor are strong, especially that many developing countries, particularly those in MENA, have similar issues and experiences.

Funding: Wallis Annenberg Foundation Grant for Research on Women and Fertility.

20 Since 2004, more than two-thirds of college students are women. 


\section{References}

Abbasi-Shavazi, M. J., P. McDonald, and M. Hosseini-Chavoshi. 2009. The Fertility Transition in Iran: Revolution and Reproduction. New York, NY: Springer.

Alizadeh, P. 2000. “Female Employment in Post-Revolutionary Iran.” In The Economy of Iran: The Dilemmas of an Islamic State, edited by P. Alizadeh, 261-287. London: I.B. Tauris.

Assaad, R., and F. El-Hamidi. 2009. "Women in the Egyptian Labor Market: An Analysis of Developments, 1988-2006." In The Egyptian Labor Market Revisited, edited by R. Assaad, 219-57. Cairo: American University in Cairo Press.

Barro, R. J., and J.-W. Lee. 2001. "International Data on Educational Attainment: Updates and Implications." Oxford Economic Papers 53(3): 541-63.

Blau, F. D., and L. M. Kahn. 2007. "Changes in the Labor Supply Behavior of Married Women: 1980-2000." Journal of Labor Economics 25: 393-438.

Blundell, R., and T. MaCurdy. 1999. "Labor Supply: A Review of Alternative Approaches." In Handbook of Labor Economics, edited by O. Ashenfelter, and D. Card, Chapter 27, 1559-1695. Amsterdam, North-Holland: Elsevier.

Esfahani, H. S., and R. Bahramitash. 2011. "The Transformation of Female Labor Market." In Veiled Employment: Islamism and a Political Economy of Women's Employment in Iran, edited by H. S. Esfahani and R. Bahramitash, 123-165. Syracuse, NY: Syracuse University Press.

Esfahani, H. S., and P. Shajari. 2012. "Gender, Education, Family Structure, and the Allocation of Labor in Iran." Middle East Development Journal 4(2): 1-40.

Hakimian, H. 2007. Labour market dynamics and employment policy in Saudi Arabia. Technical report, The International Labour Organization, Geneva.

Hayo, B., and T. Caris. 2013. "Female Labour Force Participation in the MENA Region: The Role of Identity." Review of Middle East Economics and Finance 9(3): 271-292.

Hooglund, E. 2011. "Gender in Contemporary Iran: Pushing the Boundaries." In Changing Attitudes Among Women in Rural Iran, 120-135. New York: Routledge.

İlkkaracan, í. 2012. "Why so Few Women in the Labor Market in Turkey?" Feminist Economics 18 (1): $1-37$.

Karshenas, M. 2001. “Economic Liberalization, Competitiveness and Women's Employment in the Middle East and North Africa." In Labor and Human Capital in the Middle East: Studies of Markets and Household Behavior, edited by D. Salehi-Isfahani, 147-194. London: Ithaca Press.

Keddie, N. R. 2006. Modern Iran: Roots and Results of the Revolution. New Haven, CT: Yale University Press. Updated.

Killingsworth, M. R., and J. J. Heckman. 1986. "Female Labor Supply: A Survey." In Handbook of Labor Economics, 1st edn, edited by O. C. Ashenfelter and R. Layard, Volume 1 of Handbooks in Economics, 103-204. Amsterdam, North-Holland: Elsevier.

Kurzman, C. 2008. “A Feminist Generation in Iran?” Iranian Studies 41(3): 297-321.

Majbouri, M. 2010. “Against the Wind: Labor Force Participation of Women in Iran.” Ph.D. thesis, University of Southern California.

Majbouri, M. 2015a. Against the Wind: Labor Force Participation of Women and Economic Instability in Iran. Working Paper.

Majbouri, M. 2015b. Oil, laws, and female labor force participation. Working Paper. 
Mehran, G. 2003. "The Paradox of Tradition and Modernity in Female Education in the Islamic Republic of Iran." Comparative Education Review 47(3): 269-286.

Mehryar, A. H., G. Farjadi, and M. Tabibian. 2004. "Labor Force Participation of Women in the Contemporary Iran." In Women in Iran From 1800 to Islamic Republic, edited by L. Beck, and G. Nashat, 182-203. Chicago: University of Illinois Press.

Moghadam, F. E. 2011. "Iran's Missing Working Women." In Veiled Employment: Islamism and the Political Economy of Women's Employment in Iran, edited by R. Bahramitash, and H. S. Esfahani. Syracuse, NY: Syracuse University Press.

Moghadam, V. M. 1995. "Women's Employment Issues in Contemporary Iran: Problems and Prospects in the 1990s." Iranian Studies 28(3-4): 175-202.

Moghadam, V. M. 2000. "The State and the Social Position of Women." In The Economy of Iran: The Dilemmas of an Islamic State, edited by P. Alizadeh, 233-260. London: I.B. Tauris.

Potrafke, N., and H. W. Ursprung. 2012. "Globalization and Gender Equality in the Course of Development.” European Journal of Political Economy 28: 399-413.

Sahn, D. E., and D. C. Stifel. 2000. "Poverty Comparisons Over Time and Across Countries in Africa." World Development 28(12): 2123-2155.

Salehi-Isfahani, D. 2005. "Human Resources in Iran: Potentials and Challenges." Iranian Studies 38(1): 117-147.

Salehi-Isfahani, D., M. J. Abbasi-Shavazi, and M. Hosseini-Chavoshi. 2010. "Family Planning and Fertility Decline in Rural Iran: The Impact of Rural Health Clinics." Health Economics 19 (S1): 159-180.

Salehi-Isfahani, D., and D. Egel. 2010. "Youth Transitions to Employment and Marriage in Iran: Evidence from the School to Work Transition Survey." Middle East Development Journal 2 (1): 89-120.

Sayre, E., and R. Hendy. forthcoming. "Female Labor Supply in Egypt, Tunisia, and Jordan." In Generation Awakening: The Socio-Economic Lives of Young People on the Eve of the Arab Spring, edited by E. Sayre and T. Yousef. New York, NY: Oxford University Press.

Witte, M. D. 2011. "Female Labor, Western Culture and Growth in the Gulf Cooperation Council Countries." Review of Middle East Economics and Finance 7(1): 20-31. 